\title{
The Impacts of Graphene Nanosheets and Manganese Valency on Lithium Storage Characteristics in Graphene/Manganese Oxide Hybrid Anode
}

\author{
S. L. Cheekati, Z. Yao, and H. Huang \\ Department of Mechanical and Materials Engineering, Wright State University, Dayton, OH 45435, USA \\ Correspondence should be addressed to H. Huang, hong.huang@wright.edu
}

Received 26 June 2012; Accepted 7 August 2012

Academic Editor: Chunyi Zhi

Copyright (C) 2012 S. L. Cheekati et al. This is an open access article distributed under the Creative Commons Attribution License, which permits unrestricted use, distribution, and reproduction in any medium, provided the original work is properly cited.

\begin{abstract}
Graphene nanosheets (GNS) with attached MnOx nanoparticles are studied in regard to their structure and morphology. The relationship between the lithium storage performances and GNS contents as well as manganese valency was investigated. Experimental results showed that the specimen with $44 \mathrm{wt} \%$ GNS and high content of $\mathrm{MnO}$ delivered high reversible capacity (over twice of that in graphitic carbon anode), good cycling stability ( $0.8 \%$ fading per cycle), and high rate capability (67\% at the $800 \mathrm{~mA} / \mathrm{g}$ ), which are dramatically better than pure $\mathrm{Mn}_{3} \mathrm{O}_{4}$. The improvement is attributed to the presence of GNS which provides continuous networks for fast electronic conduction and mechanical flexibility for accommodating the large volume change. The $\mathrm{MnOx} / \mathrm{GNS}$ hybrid material has the added advantages over pure GNS, benefiting from its lithium storage potential of around $0.5 \mathrm{~V}$ which not only ensures high rate capability but also reduces the risk of metallic lithium formation with its safety hazard.
\end{abstract}

\section{Introduction}

Nanoparticles of transition metal oxides $\left(\mathrm{MO}_{x}\right.$, where $\mathrm{M}$ is $\mathrm{Co}, \mathrm{Fe}, \mathrm{Ni}$, or $\mathrm{Cu}$ ) have recently received much attention as alternative anode materials for Li-ion batteries. $\mathrm{MO}_{x}$ can deliver over twice the gravimetric capacity and six times volumetric capacity in comparison with graphitic carbon anode [1-3]. The mechanism of $\mathrm{Li}$ reaction with $\mathrm{MO}_{x}$ series, differing from the classical $\mathrm{Li}$ insertion or Lialloying processes, involves the reversible formation and decomposition of $\mathrm{Li}_{2} \mathrm{O}$ accompanying the reduction and oxidation of metal nanoparticles $\mathrm{MO}_{x}+x \mathrm{Li} \Leftrightarrow x \mathrm{Li}_{2} \mathrm{O}+$ M. Although the reverse reaction is thermodynamically unfavorable and the electrochemical kinetics is sensitive to the activity of $\mathrm{Li}_{2} \mathrm{O}$ [4-6], Tarascon et al. has discovered that reducing the particle size of $\mathrm{MO}_{x}$ to nanometer scale can enhance the electrochemical activities of $\mathrm{Li}_{2} \mathrm{O}$ and metal particles driving the reversible occurrence of the formation/decomposition reaction $[1,2]$. Further, incorporating conducting additives into the nanoparticle metal oxides has improved the cycling stability [7-11]. Graphene nanosheets
(GNS), known for their superior electrical conductivities and high surface areas, have been added to MO [12-23] forming 3D nanostructured MO-GNS hybrids which led to the improvement of lithium storage performances. For instance, Lian et al. [13] prepared $\mathrm{Fe}_{3} \mathrm{O}_{4}$ /graphene hybrid material by a gas/liquid interface reaction. Electrochemical tests showed that the 22.7 wt $\% \mathrm{Fe}_{3} \mathrm{O}_{4}$ /graphene hybrid exhibited a large reversible specific capacity of $1048 \mathrm{mAh} / \mathrm{g}$ (99\% of the initial reversible specific capacity) at the 90th cycle in comparison with that of the bare $\mathrm{Fe}_{3} \mathrm{O}_{4}$ nanoparticles (only $226 \mathrm{mAh} / \mathrm{g}$ at the 34th cycle). Kim et al. [15] uniformly dispersed $\mathrm{Co}_{3} \mathrm{O}_{4}$ nanoparticles on GNS using a simple in situ reduction process. The $\mathrm{Co}_{3} \mathrm{O}_{4}$-graphene hybrid material delivered a reversible capacity around $800 \mathrm{mAh} / \mathrm{g}$ at the $0.2 \mathrm{C}$ rate with a columbic efficiency of $97 \%$ after 42 cycles.

Manganese oxide is an attractive anode candidate for its low cost and environmental friendliness. The fact that one mole of $\mathrm{MnO}$ reacts with 2 moles of $\mathrm{Li}$ corresponds to a maximum reversible lithium storage capacity of $756 \mathrm{mAh} / \mathrm{g}$. $\mathrm{Mn}_{3} \mathrm{O}_{4}$ increases the theoretical value to $936 \mathrm{mAh} / \mathrm{g}$. However, a capacity less than $300 \mathrm{mAh} / \mathrm{g}$ was constantly reported 
in the past using pure $\mathrm{Mn}_{3} \mathrm{O}_{4}$ micropowders [24]. Cobalt doping in $\mathrm{Mn}_{3} \mathrm{O}_{4}$ increased the capacity to $400 \mathrm{mAh} / \mathrm{g}$ due to the increased electrical conductivity [24]. Recently, various morphological and structural $\mathrm{MnOx}$ have been studied for anode applications in Li-ion batteries [25-28]. There are emerging reports on improving the reversible capacity, cycle life, and rate capability via dispersing $\mathrm{MnOx}$ nanoparticles in GNS [19-23]. Table 1 listed some results complied from the published literatures. The results varied in a wide range due to the variations of the synthesis approaches and, hence, the structure, morphology, and composition. Here we will report the lithium storage characteristics in GNS/nanoMnOx hybrid materials with similar morphologies but different contents of GNS and low-valent Mn component. The objective of this study is to experimentally clarify the impacts of the GNS content and manganese valency on the lithium storage characteristics in terms of Coulombic efficiency, capacity, cycle life, and rate capability.

\section{Experimental}

2.1. Synthesis of GNS Powders. GNS powders were synthesized using the traditional Hummers approach. Specifically, 1 gram graphite and 0.5 gram sodium nitrate were firstly mixed in $70 \mathrm{~mL}$ concentrated sulfuric acid. Then 3 gram potassium permanganate was gradually added to the mixture and stirred for $5 \mathrm{hrs}$ at room temperature. Afterwards, hydrogen peroxide was added to this mixture until the mixture turned into bright yellow color. This mixture was then rinsed thoroughly until the $\mathrm{pH}$ value was close to 7 . After filtered and dried, the fine powders were heat treated at $250^{\circ} \mathrm{C}$ for $6 \mathrm{hrs}$ in air. All the precursor chemicals were purchased from Aldrich.

2.2. Synthesis of GNS/MnOx Hybrid Powders. The GNS/ MnOx hybrid materials were chemically synthesized followed by appropriate thermal treatment. Initially, $22 \mathrm{mg}$ as-prepared GNS were ultrasonicated in water for $3 \mathrm{hrs}$. Then $78 \mathrm{mg}$ manganese acetate $(\mathrm{MnAc})$ dissolved in water was gradually added to the GNS suspension solution and continuously stirred for $2 \mathrm{hrs}$. Then ammonium hydroxide and hydrazine were sequentially added and mixture was stirred for $3 \mathrm{hrs}$ at $100^{\circ} \mathrm{C}$. The product was filtered and dried at $150^{\circ} \mathrm{C}$ for $3 \mathrm{hrs}$. The as-prepared powder is named as GNS/MnOx-1. GNS/MnOx-1 powders were then subjected to thermal treatment at $400^{\circ} \mathrm{C}$ for $12 \mathrm{hrs}$ in air or in $5 \%$ $\mathrm{H}_{2} / \mathrm{Ar}$ atmosphere, which are referred to as GNS/MnOx-2 and GNS/MnOx-3, respectively. The thermal treatment in air resulted in the changes of GNS content. Thermal treatment under the reduction environment altered the manganese valency state in the hybrid materials.

\subsection{Structure, Morphology, and Composition Analyses.} Bruker D8 X-ray diffractometer (XRD) was used to identify the crystal structure of the manganese component in the hybrids. JEOL scanning electron microscope (SEM) was used to visualize the morphologies. The weight loss of the powders after the thermal treatment and energy dispersive spectroscopy (EDX) were used to determine the carbon content.

\subsection{Electrode Preparation and Electrochemical Characteriza-} tions. The active anode powders were mixed with polyvinylidene fluoride (PVDF) binder in the weight ratios of $90: 10$ in $\mathrm{N}$-methylpyrrolidone (NMP) to form a viscous slurry. The slurry was uniformly coated on a $\mathrm{Cu}$ foil. The electrode sheets were dried at $120^{\circ} \mathrm{C}$ for $12 \mathrm{hrs}$ under vacuum. Swagelok cells were assembled in a glove box which controlled the moisture and oxygen levels less than $0.5 \mathrm{ppm}$. The electrolyte was $1 \mathrm{M} \mathrm{LiPF}_{6}$ dissolved in a mixture of ethylene carbonate (EC) and dimethyl carbonate (DEC) at $1: 1$ volumetric ratio. Li metal foil was used as the counter electrode. The cells were galvanostatically discharged and charged at the preset current densities within the cutoff voltage window of 0.01$3.0 \mathrm{~V}$ on a battery testing station (Land CT). Electrochemical impedance spectra (EIS) of the GNS/MnOx electrodes were obtained by applying a sine-wave signal with an amplitude of $10 \mathrm{mV}$ in the frequency range of $1 \mathrm{MHz}$ to $0.1 \mathrm{~Hz}$ on Camry electrochemical analysis system at the preset capacity interval after relaxation for $2 \mathrm{hrs}$.

\section{Results and Discussion}

Figure 1 showed the X-ray diffraction (XRD) profiles of the as-prepared GNS and all the three GNS-MnOx hybrid materials. For comparison, the profile of a simple mixture of GNS and MnAc was included in the figure. In the as-prepared GNS profile, there was only one broad peak centered at $24.6^{\circ}$. This is the characteristic XRD spectrum of GNS. Neither the diffraction peak corresponding to the crystalline graphite (e.g., $26.5^{\circ}$ ) nor that to graphene oxide (e.g., $10.8^{\circ}$ ) was observed, confirming the exfoliation of the graphite into reduced graphene oxide nanosheets. Crystalline manganese acetate $(\mathrm{MnAc})$ can only transform into the $\mathrm{Mn}_{3} \mathrm{O}_{4}$ phase after thermal decomposition above $400^{\circ} \mathrm{C}$ in air. However, in the as-prepared GNS/MnOx-1 obtained by mixing MnAc and GNS in an aqueous solution followed by the facile chemical hydrolysis processing at $150^{\circ} \mathrm{C}$, all $\mathrm{MnAc}$ related diffraction peaks disappeared. Instead, the observed peaks corroborated well with the $\mathrm{Mn}_{3} \mathrm{O}_{4}$ crystalline phase. Based on the width of diffraction peaks, the particle size of $\mathrm{Mn}_{3} \mathrm{O}_{4}$ was estimated around $30 \mathrm{~nm}$. Thermal treatment at $400^{\circ} \mathrm{C}$ in air (see the profile of GNS/MnOx-2) neither altered the phase of $\mathrm{Mn}_{3} \mathrm{O}_{4}$ nor the widths of the diffraction peaks indicating insignificant increase of the particle sizes. In the profile of GNS/MnOx-3 obtained after treatment at $400^{\circ} \mathrm{C}$ in the $\mathrm{H}_{2} /$ Ar environment, the $\mathrm{MnO}$ diffraction peaks emerged, which were labeled with the stars. $\mathrm{MnO}$ is the common reduction product of $\mathrm{Mn}_{3} \mathrm{O}_{4}$. Semiquantitative analyses, from the XRD results, suggested that the atomic ratio of $\mathrm{MnO}$ to $\mathrm{Mn}_{3} \mathrm{O}_{4}$ was around $3: 2$.

The carbon and manganese content was determined using EDX microelemental composition analysis attached to the SEM instrument. To ensure the results consistency and relative accuracy, five different regions with different area sizes were chosen on each specimen compositional analyses. 
TABLE 1: Complied information MnOx and GNS/MnOx composites in published literatures including their prepared conditions, manganese component phases, GNS contents, and electrochemical performances.

\begin{tabular}{|c|c|c|c|c|c|}
\hline Sample & Morphology & Basic synthesis info & $\begin{array}{l}1 \text { st } d / c \text { capacities } \\
(\mathrm{mAh} / \mathrm{g}), \text { efficiency }\end{array}$ & $\begin{array}{l}\text { Rate capability } \\
(\mathrm{mAh} / \mathrm{g} \text { at } \mathrm{mA} / \mathrm{g})\end{array}$ & Reference \\
\hline $\mathrm{MnO}_{2}$ & \multirow{4}{*}{$\begin{array}{l}\text { rodlike } 100-150 \mathrm{~nm} \text { in } \\
\text { diameter, } 1-2 \mu \mathrm{m} \text { in length }\end{array}$} & $\begin{array}{l}\mathrm{MnAc}+(\mathrm{NH} 4)_{2} \mathrm{~S}_{2} \mathrm{O}_{7}, 140^{\circ} \mathrm{C} 2 \mathrm{~h} \text { to form } \\
\text { amorphous } \mathrm{MnO}_{2}, 500^{\circ} \mathrm{C} 10 \mathrm{~h}\end{array}$ & $1146 / 627,55 \%$ & \multirow{4}{*}{ No info } & {$[26]$} \\
\hline $\mathrm{Mn}_{2} \mathrm{O}_{3}$ & & ibid amorphous $\mathrm{MnO}_{2}, 350^{\circ} \mathrm{C} 10 \mathrm{~h}$ & $1156 / 547,47 \%$ & & {$[26]$} \\
\hline $\mathrm{Mn}_{3} \mathrm{O}_{4}$ & & $\begin{array}{l}\text { ibid amorphous } \mathrm{MnO}_{2}, 280^{\circ} \mathrm{C} 3 \mathrm{~h} \text { in } \\
\mathrm{H}_{2} / \mathrm{Ar}, 700^{\circ} \mathrm{C} 2 \mathrm{~h} \text { in } \mathrm{Ar}\end{array}$ & $1265 / 528,42 \%$ & & {$[26]$} \\
\hline $\mathrm{MnO}$ & & $\begin{array}{l}\text { ibid amorphous } \mathrm{MnO}_{2}, 400^{\circ} \mathrm{C} 10 \mathrm{~h} \text { in } \\
\mathrm{H}_{2} / \mathrm{Ar}, 700^{\circ} \mathrm{C} 2 \mathrm{~h} \text { in } \mathrm{Ar}\end{array}$ & $1728 / 488,28 \%$ & & {$[26]$} \\
\hline $\mathrm{MnO}$ & $\begin{array}{l}\text { agglomerate } \\
0.5-1.5 \mu \mathrm{m}\end{array}$ & $\begin{array}{l}\text { MnO-L (commercial) } \\
\text { C-coated (C/MnO-L) }\end{array}$ & $\begin{array}{l}1270 / 690,53 \% \\
1080 / 670,62 \%\end{array}$ & 300 at 800 & {$[27]$} \\
\hline $\mathrm{MnO}$ & $\begin{array}{l}\text { Sheets, } \\
0.5-1.5 \mu \mathrm{m}\end{array}$ & $\begin{array}{l}\mathrm{MnO}-\mathrm{S} \text { (ball milled }) \\
\text { C-coated (C/MnO-S) }\end{array}$ & $\begin{array}{l}1240 / 750,61 \% \\
1080 / 700,65 \%\end{array}$ & 300 at 800 & {$[27]$} \\
\hline $\mathrm{Mn}_{3} \mathrm{O}_{4}$ & $\begin{array}{l}\text { spongelike } \\
30-80 \mathrm{~nm}\end{array}$ & $\mathrm{Mn}\left(\mathrm{CH}_{3} \mathrm{COO}\right)_{2}+\mathrm{NH}_{4} \mathrm{OH}, 300^{\circ} \mathrm{C} 5 \mathrm{~h}$ & $1327 / 869,65 \%$ & 520 at 500 & {$[28]$} \\
\hline $\mathrm{Mn}_{3} \mathrm{O}_{4} / \mathrm{GNS}$ & $20-30 \mathrm{~nm}$ & $\begin{array}{l}\mathrm{GO}+\mathrm{MnCl}_{2} \cdot 2 \mathrm{H}_{2} \mathrm{O}+\mathrm{KMnO}_{4}+ \\
\mathrm{NH}_{4} \mathrm{OH}, \\
80^{\circ} \mathrm{C} 8 \mathrm{~h}, 120^{\circ} \mathrm{C} \text { dried, GNS } 15 \mathrm{wt} \%\end{array}$ & $1789 / 1100,62 \%$ & 400 at 1000 & {$[22]$} \\
\hline $\mathrm{Mn}_{3} \mathrm{O}_{4} / \mathrm{GNS}$ & $30-50 \mathrm{~nm}$ & $\begin{array}{l}\mathrm{GO}+\mathrm{Mn}\left(\mathrm{CH}_{3} \mathrm{COO}\right)_{2}+\mathrm{NaOH}, \\
\text { hydrothermal } 180^{\circ} \mathrm{C} \text { for } 12 \mathrm{~h}, \mathrm{GNS} \\
15 \mathrm{wt} \%\end{array}$ & $1100 / 750,68 \%$ & 610 at 200 & {$[23]$} \\
\hline $\mathrm{MnO} / \mathrm{GNS}$ & $30-50 \mathrm{~nm}$ & $\begin{array}{l}\text { ibid, then } 400^{\circ} \mathrm{C} 2 \mathrm{~h} \text { in } \mathrm{H}_{2} / \mathrm{N}_{2} \text {, GNS } \\
12 \mathrm{wt} \%\end{array}$ & $1320 / 820,62 \%$ & 200 at 600 & {$[23]$} \\
\hline $\mathrm{Mn}_{3} \mathrm{O}_{4} / \mathrm{GNS}$ & $10-20 \mathrm{~nm}$ & $\begin{array}{l}\mathrm{GO}+\mathrm{Mn}\left(\mathrm{CH}_{3} \mathrm{COO}\right)_{2} \text {, hydrolysis, } \\
\text { hydrothermal at } 180^{\circ} \mathrm{C} \text { for } 10 \mathrm{~h}, 10 \mathrm{wt} \% \\
\text { RGO }\end{array}$ & $1320 / 850,64 \%$ & 600 at 800 & {$[19]$} \\
\hline $\mathrm{MnO}_{2} / \mathrm{GNS}$ & $\begin{array}{l}70-80 \mathrm{~nm} \\
\text { diameter }\end{array}$ & $\begin{array}{l}\mathrm{GO}+\mathrm{MnO}_{2} \text { nanotube hydrothermal } \\
\text { from } \mathrm{KMnO}_{4} \text {, layer by layer assembly }\end{array}$ & $1232 / 686,55.7 \%$ & 300 at 800 & {$[24]$} \\
\hline
\end{tabular}

The average carbon contents in the three specimens were $44 \mathrm{wt} \%, 20 \mathrm{wt} \%$, and $42 \mathrm{wt} \%$, respectively.

Although the GNS/MnOx-1 was prepared from GNS and MnAc, XRD analyses confirmed no existence of MnAc and all the $\mathrm{Mn}$ component had been transformed into $\mathrm{Mn}_{3} \mathrm{O}_{4}$. Accordingly, from the weight of the precursors, the GNS composition in the GNS/MnOx-1 was calculated to be $44 \mathrm{wt} \%$, consistent with the EDX analyses. When the GNS $/ \mathrm{MnO}_{x}-1$ was thermally treated in air at $400^{\circ} \mathrm{C}$, the specimen lost $30 \%$ of the total weight. Control experiment at the same condition on pure GNS verified the occurrence of the GNS combustion. Further, since $\mathrm{Mn}_{3} \mathrm{O}_{4}$ neither decomposed nor evaporated at $400^{\circ} \mathrm{C}$, all the weight loss originated from the GNS combustion into $\mathrm{CO}_{2}$. Accordingly, the GNS content in the GNS/MnOx-2 was determined to be $20 \mathrm{wt} \%$. In contrast, heat treatment under the $\mathrm{H}_{2} / \mathrm{Ar}$ reduction/inert atmosphere mainly resulted in reduction of $\mathrm{Mn}_{3} \mathrm{O}_{4}$ into $\mathrm{MnO}$ but insignificant combustion of GNS. Based on the $4.5 \mathrm{wt} \%$ weight loss of GNS/MnOx-1 under the experimental condition $\left(400^{\circ} \mathrm{C}\right.$ for $\left.12 \mathrm{hrs}\right)$, it was calculated that the $\mathrm{MnO}$ to $\mathrm{Mn}_{3} \mathrm{O}_{4}$ ratio in the GNS/MnOx3 was $61: 39$, corroborated well with XRD semiquantitative analysis. Table 2 listed the phase and compositional content in all the three GNS/MnOx hybrid materials.

SEM imaging was used to visualize the particle morphological evolution from GNS to GNS/MnOx hybrids.
GNS exhibited thin wrinkled flakes suggesting high surface area (see Figures 2(a) and 2(b)). Atomic force microscopic images also confirmed the existence of the monolayer graphene, which was presented elsewhere [20]. The GNS prepared from the Hummer's approach usually contains epoxyl, hydroxyl, and carboxyl function groups on the surface and the edges, resulting in the wrinkled morphology. When GNS is present in an $\mathrm{Mn}^{2+}$ containing solution, the $\mathrm{Mn}^{2+}$ ions can react with the functional groups on GNS resulting in strong chemical absorption. Hydrolysis and drying process transform the anchored $\mathrm{Mn}^{2+}$ ions into the $\mathrm{Mn}_{3} \mathrm{O}_{4}$ phase. Figures 2(c) and 2(d) revealed that manganese oxide nanoparticles homogeneously bonded on both sides of the crumpled and corrugated graphene oxide nanosheets. The SEM images of GNS/MnOx-3 were very similar to those of GNS/MnOx-1 and hence not shown in the paper. The GNS embedded with $\mathrm{MnO}_{x}$ nanoparticles may stack or cross-link forming a multilayer sandwich structure leading to relatively thick flaky type morphology than GNS. The sandwich structural morphology is beneficial for the lithium storage electrochemical reaction. On the one hand, the GNS flakes provide direct electrical conducting paths and strain buffers to accommodate the volume changes of the $\mathrm{MnOx}$ nanoparticles. On the other hand, the anchored $\mathrm{MnO}_{x}$ nanoparticles can serve as spacers to prevent the restacking of individual graphene nanosheets. Consequently, 


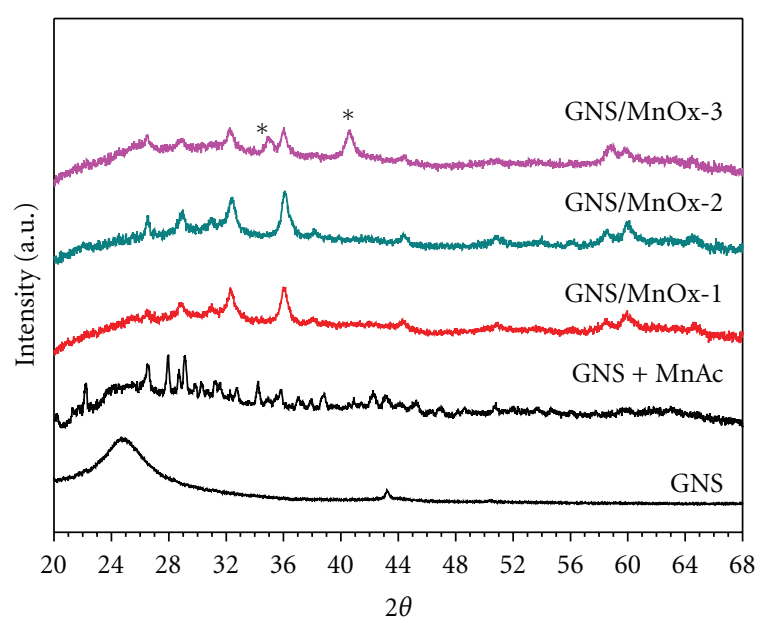

FIGURE 1: XRD profiles of the GNS/MnOx nanocomposites in comparison with precursors GNS and GNS+MnAc.

the interaction between the $\mathrm{MnO}_{x}$ and GNS prevented the agglomeration of the $\mathrm{MnO}_{x}$ as well as GNS.

After the $\mathrm{GNS} / \mathrm{MnOx}-1$ was subjected to $400^{\circ} \mathrm{C}$ sintering in air, the flaky structure transformed into the loose fluffy agglomerates in some areas, revealed from the circled region in the image of GNS/MnOx-2 (Figure 2(f)). The thermal treatment resulted in partial burnoff of GNS. Consequently, some $\mathrm{Mn}_{3} \mathrm{O}_{4}$ nanoparticles existed as freestanding agglomerates. These areas are similar to MnAc-400, the decomposition product of bare MnAc (in the absence of GNS) after $400^{\circ} \mathrm{C}$ treatment in air for $12 \mathrm{hrs}$, showing large spherical agglomerates (see Figures 2(g) and 2(h)). Such morphology is less favorable in terms of electrical conduction and mechanical stability for reversible lithium storage.

Figures 3(a)-3(d) showed the first, second, fifth, and tenth discharge-charge profiles of the GNS and GNS/MnO anodes, respectively. The 1st discharge profile of pure GNS exhibited a rapid decrease to $1.2 \mathrm{~V}$ followed by a progressively decreasing with a midpoint of around $0.5 \mathrm{~V}$. Upon charging, the profile progressively increased with a midpoint of around $1.5 \mathrm{~V}$. The large voltage hysteresis and no distinguishable plateau throughout the entire discharge/charge profile are the characteristics of lithiation/delithiation in pure GNS. The first discharge and charge capacities of lithium storage in the GNS specimen are $1248 \mathrm{mAh} / \mathrm{g}$ and $843 \mathrm{mAh} / \mathrm{g}$ with a Coulombic efficiency of $68 \%$. The irreversible capacity is the consequence of the solid electrolyte interphase (SEI) formation, irreversible lithium absorption, and electrolyte reaction with the functional groups on the GNS. The high reversible capacity of the GNS, over twice amount of the value of graphitic carbon, is attributed to the lithium storage on both sides of the graphene surface and in the abundant nanopores, defects, edges, and functional groups of GNS. In the following ten cycles, the reversible capacity faded insignificantly and the columbic efficiency was over $95 \%$ in average. The general lithium storage reaction in GNS can be expressed as follows:

$$
\mathrm{GNS}+x \mathrm{Li}^{+}+x \mathrm{e}^{-} \Longleftrightarrow \mathrm{Li}_{x} \mathrm{GNS}
$$

When $\mathrm{Mn}_{3} \mathrm{O}_{4}$ nanoparticles are anchored on the GNS, significant changes are observed in the profiling shapes (see Figures 3(b) to 3(d)). The first initial discharge/charge capacities for the three $\mathrm{GNS} / \mathrm{MnO}_{x}$ specimens are $1430 / 850$, $1504 / 578$, and 1344/838 mAh/g with Coulombic efficiencies of $59 \%, 40 \%$, and $65 \%$, respectively. The first discharge profile may be roughly divided into three regions, that is, the sloped region above $0.5 \mathrm{~V}$ (high-voltage slope region), a plateau between 0.3 and $0.5 \mathrm{~V}$, and a slope below $0.3 \mathrm{~V}$ (low-voltage slope region). In the high-voltage slope region, for specimens GNS/MnOx-1 and GNS/MnOx-3, a short segment with an inflection point of $1.25 \mathrm{~V}$ appeared. Fang et al. [25] reported that this segment was related to lithium insertion into $\mathrm{Mn}_{3} \mathrm{O}_{4}$ to form $\mathrm{LiMn}_{3} \mathrm{O}_{4}$ as follows:

$$
\mathrm{Mn}_{3} \mathrm{O}_{4}+x \mathrm{Li}^{+}+x e^{-} \Longrightarrow \mathrm{Li}_{x} \mathrm{Mn}_{3} \mathrm{O}_{4} .
$$

The remaining high-voltage slope was the contribution from the irreversible SEI reaction on the surface of GNS and manganese oxide particles as well as the phase transformation from $\mathrm{LiMn}_{3} \mathrm{O}_{4}$ to $\mathrm{MnO}$ as follows:

$$
\mathrm{LiMn}_{3} \mathrm{O}_{4}+\mathrm{Li}^{+}+e^{-} \Longleftrightarrow 3 \mathrm{MnO}+\mathrm{Li}_{2} \mathrm{O} .
$$

Since the reactions (2) and (3) as well as the SEI formation are irreversible, they are mainly observed during the first discharge. Comparing the profiles of GNS/MnOx1 with GNS/MnOx-2 (see Figures 3(b) and 3(c)), it is interesting to note that the length of the high-voltage slope is sensitive to the GNS content. Insignificant high-voltage slope was observed in the GNS/MnOx-2 profile. The phenomenon can be attributed to the less content of GNS and hence low electronic conductivity of the electrode, which resulted in the large impedance and overvoltage. The irreversible reactions occurred simultaneously with the following manganese oxide reduction around $0.4 \mathrm{~V}$ in $\mathrm{GNS} / \mathrm{MnOx}-2$.

The capacity around the $0.4 \mathrm{~V}$ plateau and below in the GNS/MnOx hybrid anodes reflected the displacement reaction between $\mathrm{Li}$ and manganese oxide $[20,22,23]$ as follows:

$$
\mathrm{MnO}+2 \mathrm{Li}^{+}+2 e^{-} \Longleftrightarrow \mathrm{Mn}+\mathrm{Li}_{2} \mathrm{O}
$$

Partial capacity in the low-voltage slope region is correlated with lithium storage in GNS (compare with Figure 3(a)). In the first charging process, it can be seen that the reverse reaction corresponding to metallic $\mathrm{Mn}$ oxidation to $\mathrm{MnO}$ mainly occurred in the range of 0.5 to $1.5 \mathrm{~V}$. Comparing the three hybrid materials (see Table 2 and Figure 3), the specimens with $44 \mathrm{wt} \%$ GNS apparently delivered higher reversible capacity and higher Coulombic efficiency than the one with $20 \mathrm{wt} \%$ GNS.

According to previous ex-situ XRD or Raman analyses $[22,25], \mathrm{Mn}$ is mainly oxidized to nanosized $\mathrm{MnO}$ after fully charged to $3.0 \mathrm{~V}$ whether the starting materials are $\mathrm{MnO}, \mathrm{Mn}_{3} \mathrm{O}_{4}$, or $\mathrm{MnO}_{2}$. Since only the reaction (4) is reversible, high valency manganese oxide will contribute to extra irreversible formation of $\mathrm{Li}_{2} \mathrm{O}$ leading to the increased irreversible capacity loss. For instance, in $\mathrm{Mn}_{3} \mathrm{O}_{4}$, the extra $1 / 3$ of $\mathrm{Li}_{2} \mathrm{O}$ could not be recovered during charging. 
TABLE 2: Summary of GNS and three GNS-MnOx specimens including their prepared conditions, manganese component phases, GNS contents, and electrochemical performances.

\begin{tabular}{lcccc}
\hline Sample & GNS & GNS/MnOx-1 & GNS/MnOx-2 & GNS/MnOx-3 \\
\hline Synthesis info & As-prepared & As-prepared & $400^{\circ} \mathrm{C} 12 \mathrm{~h}$ in air & $400^{\circ} \mathrm{C} 12 \mathrm{~h}$ in $5 \% \mathrm{H}_{2} / \mathrm{Ar}$ \\
GNS content & $100 \%$ & $44 \%$ & $20 \%$ & $42 \%$ \\
MnOx phase & $\mathrm{N} / \mathrm{A}$ & $\mathrm{Mn}_{3} \mathrm{O}_{4}$ & $\mathrm{Mn}_{3} \mathrm{O}_{4}$ & $\mathrm{Mn}_{3} \mathrm{O}_{4}+\mathrm{MnO}(40: 60)$ \\
1st capacity & $1248 / 843$ & $1430 / 850$ & $1433 / 578$ & $1279 / 838$ \\
1st efficiency & $68 \%$ & $59 \%$ & $40 \%$ & $65 \%$ \\
2nd capacity & 810 & 806 & 494 & 772 \\
10th capacity & 790 & 619 & 233 & 719 \\
Capacity fading & $0.3 \%$ & $2.6 \%$ & $5.9 \%$ & $0.8 \%$ \\
\hline
\end{tabular}

The more $\mathrm{Mn}_{3} \mathrm{O}_{4}$ in the starting materials the less Coulombic efficiency. From Table 2 and Figure 3, it is notable that GNS/MnOx-3 which contains more $\mathrm{MnO}$ has a better efficiency than GNS/MnOx-1.

Figures 3(a)-3(d) also showed the 2nd, 5th, and 10th discharge/charge profiles of the four samples. The shape of the profiles insignificantly altered from the second cycle onwards, indicating the relative stability of the hybrid anodes. After the first cycle, GNS/MnOx-1 and GNS/MnOx3 showed Columbic efficiencies over $92 \%$. In contrast, the GNS/ $\mathrm{MnO}_{x}-2$ anode had an average columbic efficiency of $80 \%$ in the following nine cycles. Figure 3(e) plotted the capacity data as a function of the cycle number. The data of $\mathrm{Mn}_{3} \mathrm{O}_{4}$ and $\mathrm{Mn}_{2.6} \mathrm{Co}_{0.4} \mathrm{O}_{4}$ were replotted from [22] for comparison. The capacity fading rates are calculated $0.3 \%, 2.6 \%$, $5.9 \%$, and $0.8 \%$ for GNS, GNS/MnOx-1, GNS/MnOx-2, and GNS/MnOx-3, respectively. The capacities of GNS/MnOx2 rapidly faded to the level of pure micro- $\mathrm{Mn}_{3} \mathrm{O}_{4}$ due to the lack of GNS. In contrast, the presence of sufficient GNS as in $\mathrm{GNS} / \mathrm{MnOx}-1$ and $\mathrm{GNS} / \mathrm{MnOx}-3$ provided continuous electrical conducting paths and buffer capability to mitigate the volume change and manganese agglomeration in the cycling process. Finely tuning the GNS content to optimize the capacity and cycle life is still in progress. The better cycling stability of GNS/MnOx-3 than GNS/MnOx-1 can be ascribed to the higher content of $\mathrm{MnO}$ in the former. GNS/MnOx-3 displayed slightly inferior to pure GNS in terms of reversible capacity and cycleability, suggesting the limited reversibility of the displacement reaction of $\mathrm{MnOx}$.

The discharge/charge profiles of the four samples obtained at different discharge rate from $50 \mathrm{~mA} / \mathrm{g}$ to $800 \mathrm{~mA} / \mathrm{g}$ are presented in Figures 4(a)-4(d). Figure 4(e) plots the discharge capacity as a function of the current rate. Among the three hybrid samples, the GNS/MnOx-3 showed the best performance for its high content of GNS and $\mathrm{MnO}$. It is worthy to note that GNS/MnOx-3 is superior to pure GNS in view of the rate capability. At the current rate increased from $50 \mathrm{~mA} / \mathrm{g}$ to $800 \mathrm{~mA} / \mathrm{g}$, the capacity decreased from $810 \mathrm{mAh} / \mathrm{g}$ to $425 \mathrm{mAh} / \mathrm{g}$ (52.4\%) for GNS. While for GNS/MnOx-3, there is still $67 \%$ of the full capacity at the $800 \mathrm{~mA} / \mathrm{g}$ rate.

Capacity loss at increasing current rate roots from the electrode kinetics and overpotential induced loss. The charge transfer impedances can be derived from electrochemical impedance spectroscopy analyses. As can be seen from Figures 5(a) and 5(b), GNS/MnOx-2 had much higher charge transfer resistance than the others. It can also be seen that the overvoltage of GNS/MnOx-2 is around twice of that GNS/MnOx-1 or GNS/MnOx-3 (compare Figure 4(c) with Figure $4(\mathrm{~b})$ or Figure $4(\mathrm{~d}))$. Both the large charge transfer resistance and high overvoltage contributed to the poor rate capability of GNS/MnOx-2.

Comparing the EIS spectra of GNS and GNS/MnOx-3, the values of the charge transfer impedances were almost the same, which excluded the difference of electrode kinetics. The difference in rate capability can be interpreted from their different discharge profiling. From the GNS discharge profile, it can be seen that major capacity is delivered at the potential region less than $0.3 \mathrm{~V}$. Since the cutoff potential was preset to $10 \mathrm{mV}$ to avoid metallic lithium formation, any polarization caused by increasing discharge current is equivalent to shift the cutoff voltage upwards. Consequently, the capacity will be ineffectively used due to up-shifting cutoff baseline. For instance, when the current rate increased from $50 \mathrm{~mA} / \mathrm{g}$ to $800 \mathrm{~mA} / \mathrm{g}$, the overvoltage was around $300 \mathrm{mV}$ (see Figure $4(\mathrm{~d}))$. The capacity read from the discharge profile of GNS at $50 \mathrm{~mA} / \mathrm{g}$ at the cutoff voltage of $300 \mathrm{mV}$ was $410 \mathrm{mAh} / \mathrm{g}$. The value was close to the capacity ( $425 \mathrm{mAh} / \mathrm{g}$ ) obtained the $800 \mathrm{~mA} / \mathrm{g}$ discharge rate. In contrast, the majority capacity of GNS/MnOx-3 was delivered above $0.3 \mathrm{~V}$. The cutoff baseline shifting upwards due to the polarization has less significant impacts on the capacity loss. At $300 \mathrm{mV}$ polarization, the capacity of $475 \mathrm{mAh} / \mathrm{g}$ was still maintained. It is therefore proposed that when the charge transfer kinetics is sufficiently high, the high discharge potential plateau around $0.5 \mathrm{~V}$ for GNS/MnOx anode is beneficial to achieve the high rate capability. The high reversible lithium storage potential value versus $\mathrm{Li}$ for $\mathrm{MnOx}$-based anode is also advantageous to prevent the possibility of metallic lithium resulting from over-discharge and at high-rate discharge, as occurred in carbon $(<0.2 \mathrm{~V})$ or Si-base anode (average $0.35 \mathrm{~V})$, and hence alleviate the safety issue.

\section{Conclusion}

In this paper, structure, morphology, and lithium storage performances in terms of first Coulombic efficiency, cycling stability, and rate capability are characterized in GNS/MnOx 


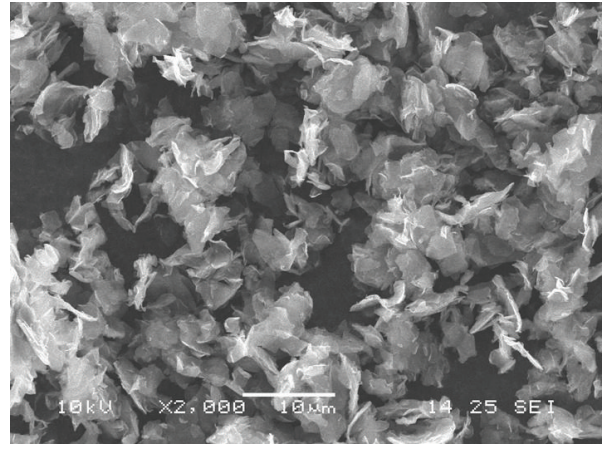

(a)

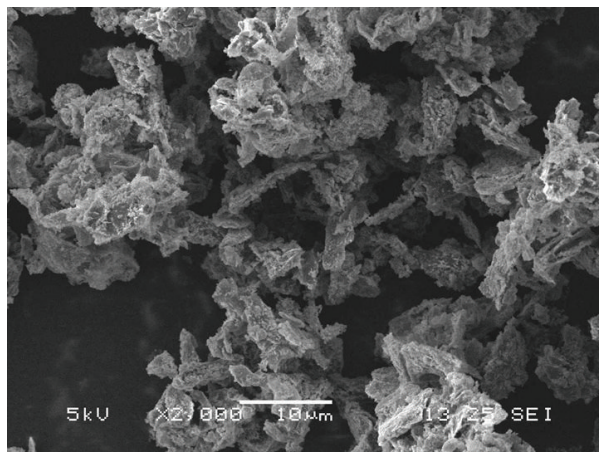

(c)

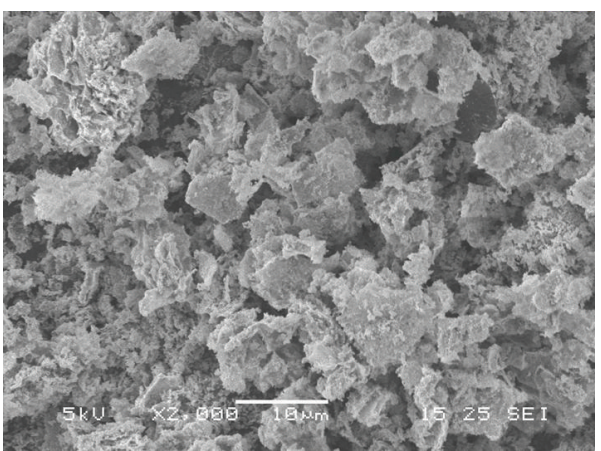

(e)

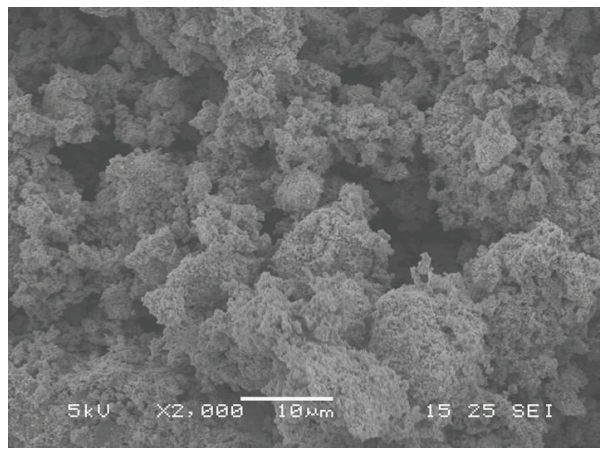

(g)

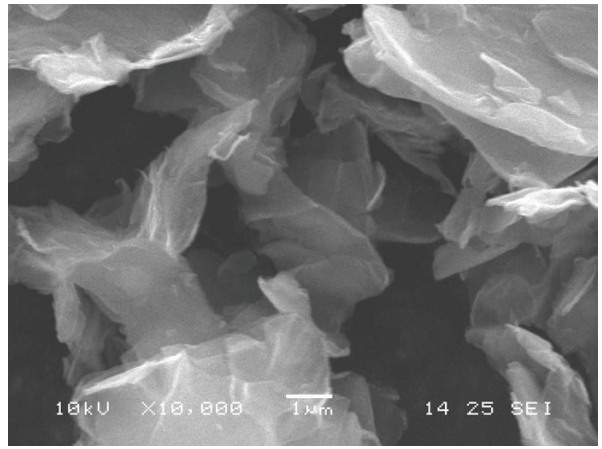

(b)

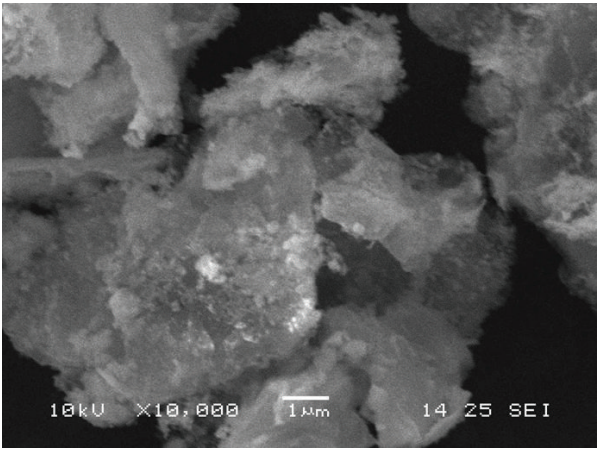

(d)

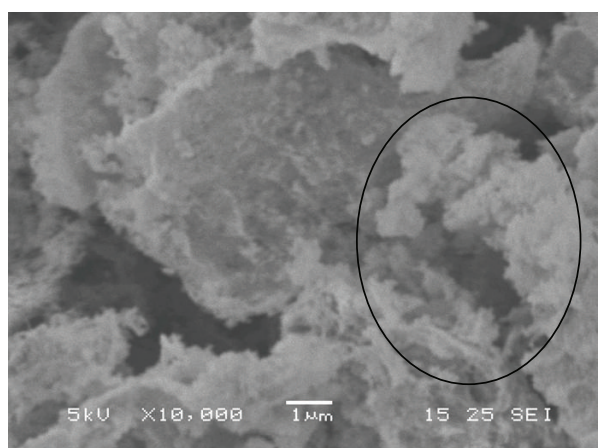

(f)

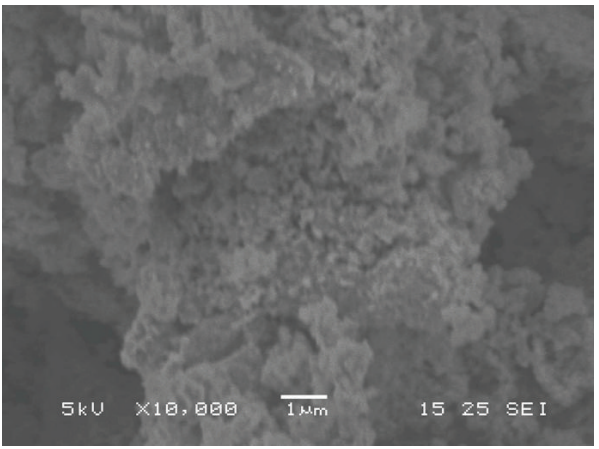

(h)

FIgURE 2: SEM images of GNS and GNS/MnOx specimens at the low magnification (left column) and high magnification (right column). (a)-(b) GNS; (c)-(d) GNS/MnOx-1; (e)-(f) GNS/MnOx-2; (g)-(h) MnAc400 (MnAc thermally decomposed at $400^{\circ} \mathrm{C}$ ). 


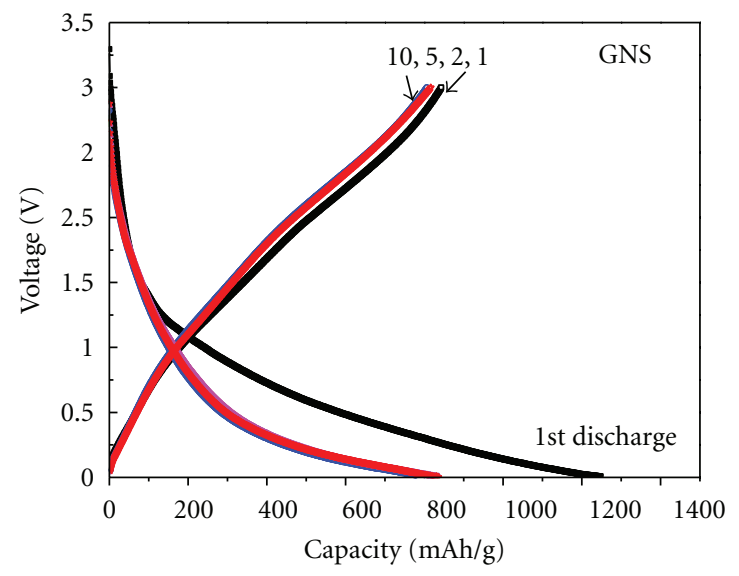

(a)

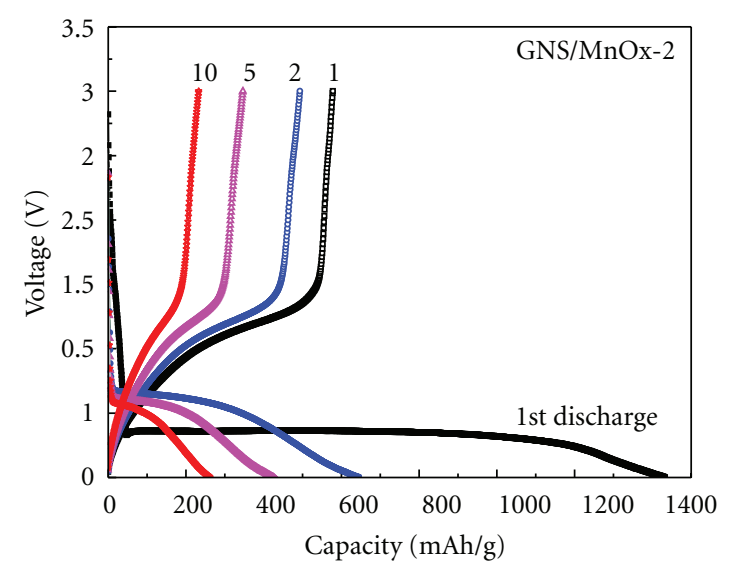

(c)

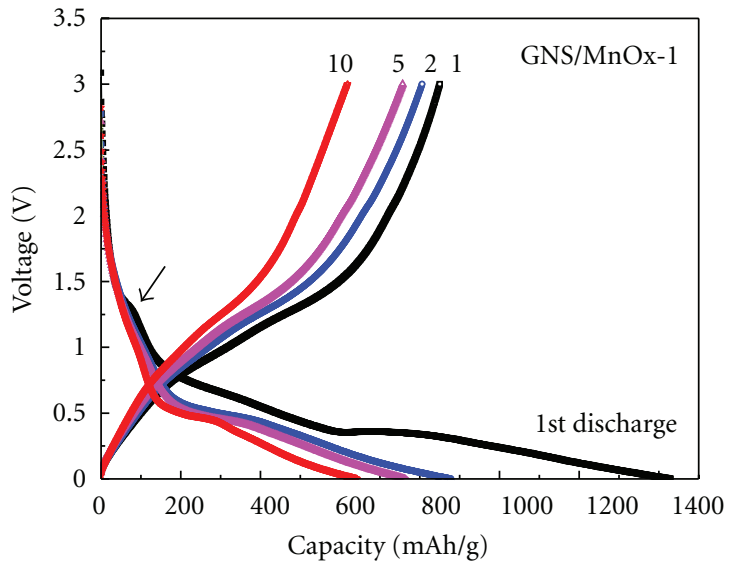

(b)

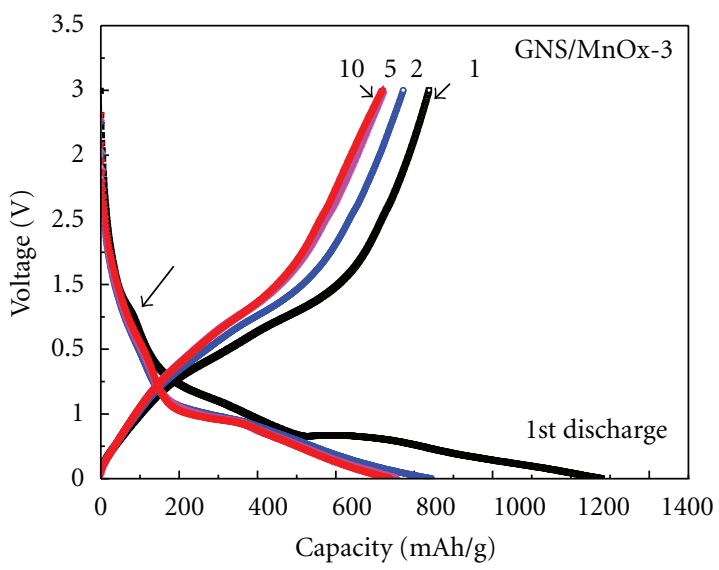

(d)

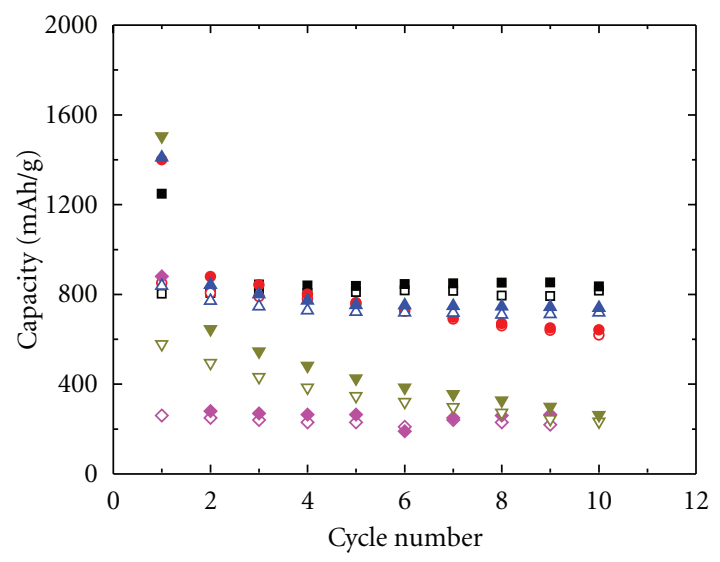

$$
\begin{array}{llll}
\text { GNS: } & \square \text { charge; } \\
\text { GNS/MnOx-1: } & \circ \text { charge; } & \bullet \text { discharge } \\
\text { GNS/MnOx-2: } & \nabla \text { charge; } & \nabla \text { discharge } \\
\mathrm{GNS} / \mathrm{MnOx}-3: & \Delta \text { charge; } \Delta \text { discharge } \\
\mathrm{Mn}_{3} \mathrm{O}_{4}: & \diamond \text { charge; } \quad \text { discharge }
\end{array}
$$

(e)

Figure 3: The 1st, 2nd, 5th, and 10th discharge-charge profiles of (a) GNS; (b) GNS/MnO${ }_{x}-1$; (c) $\mathrm{GNS} \mathrm{MnO}_{x}-2$; (d) $\mathrm{GNS} / \mathrm{MnO}_{x}-3$. (e) Cycling performance of GNS/MnOx nanocomposites in comparison with pure GNS and $\mathrm{Mn}_{3} \mathrm{O}_{4}$ (from [22]). The discharge/charge rate is $50 \mathrm{~mA} / \mathrm{g}$. 


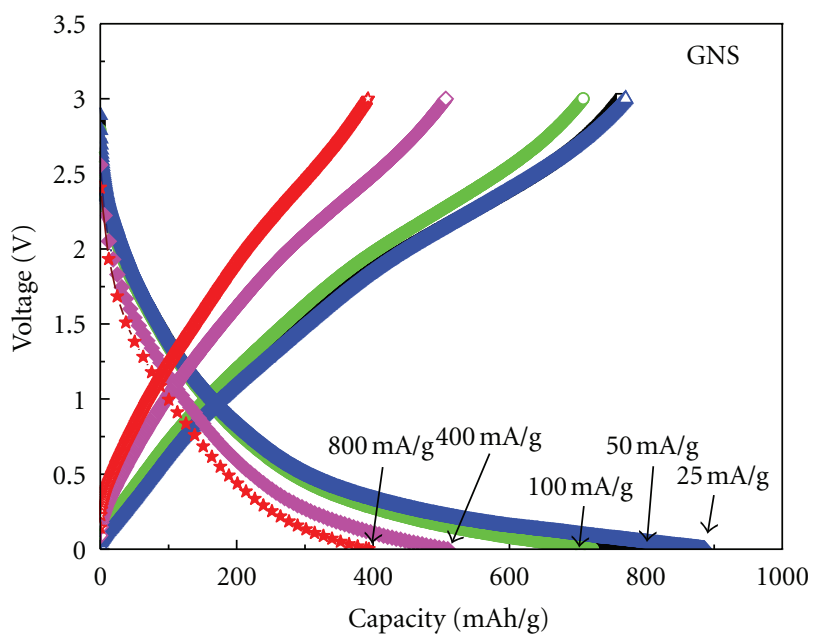

(a)

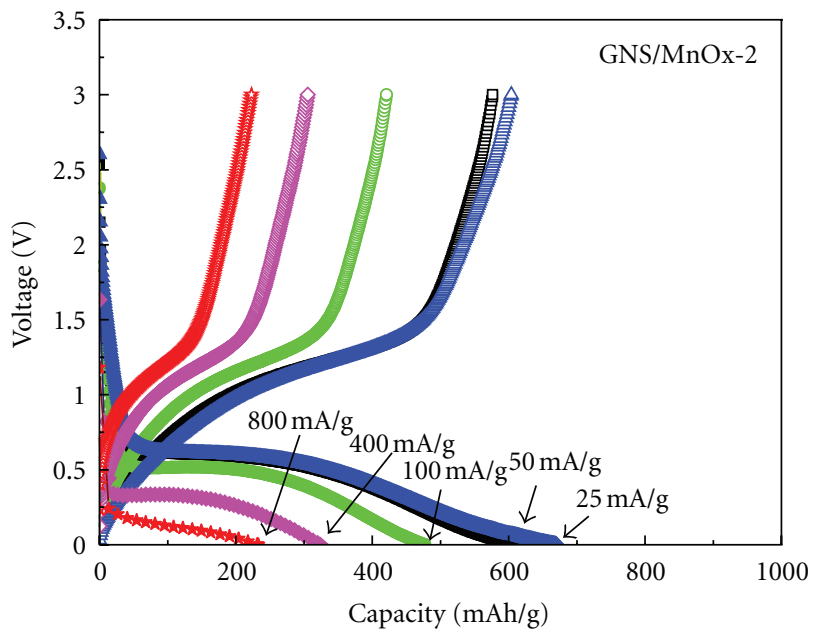

(c)

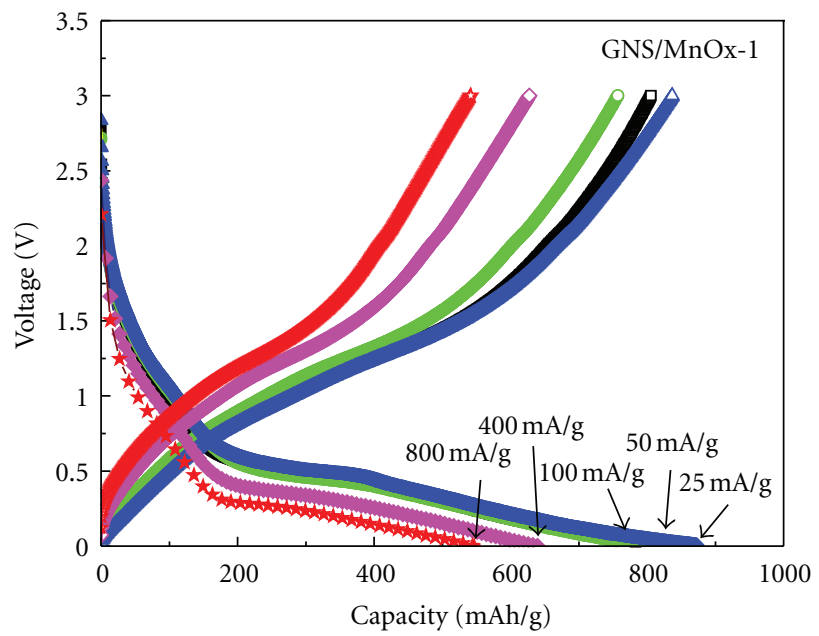

(b)

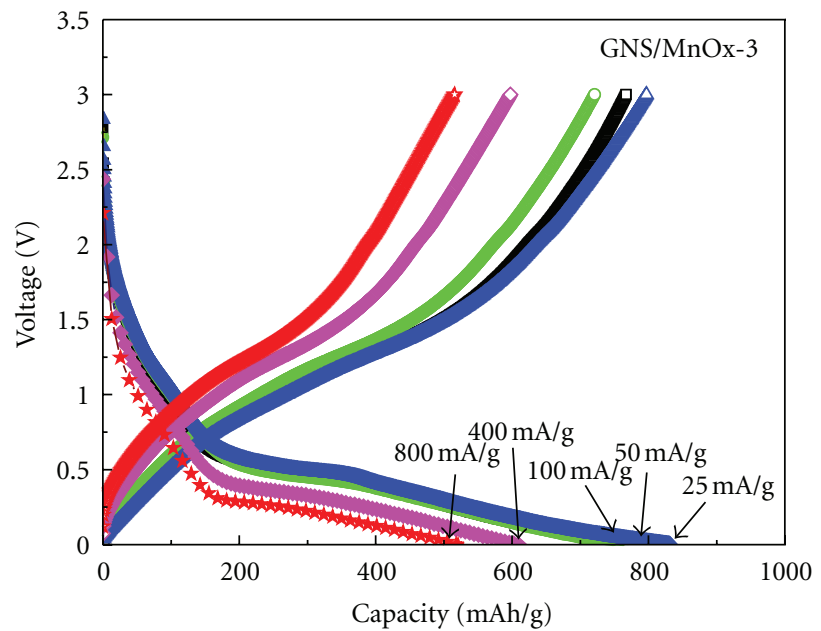

(d)

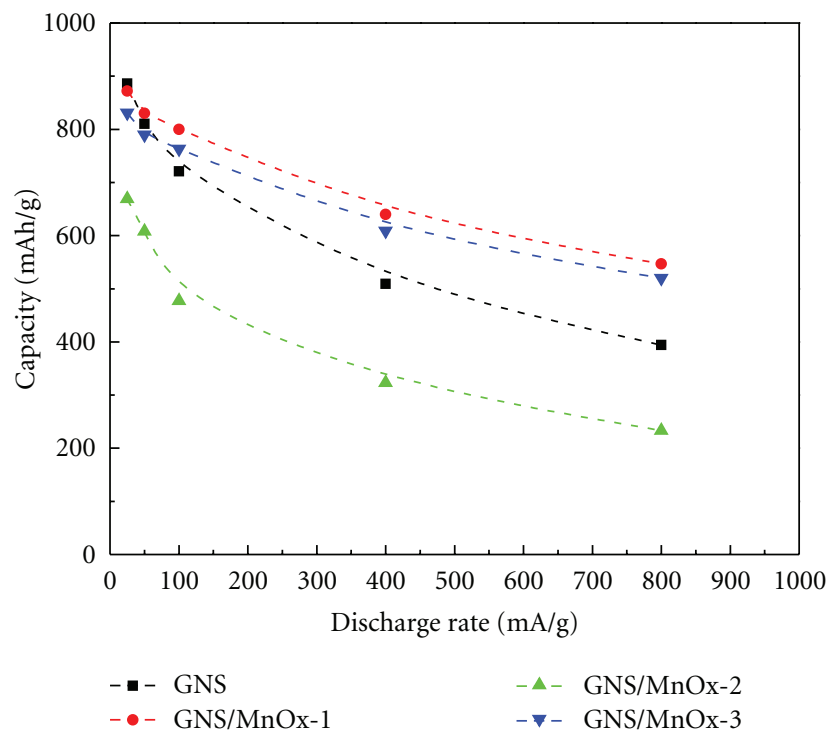

(e)

FIGURE 4: Discharge-charge profiles of (a) GNS; (b) GNS/MnO ${ }_{x}-1$; (c) GNS/MnO $\mathrm{Mn}_{x}-2$; (d) $\mathrm{GNS} / \mathrm{MnO}_{x}-3$. The discharge rates increase from $25 \mathrm{~mA} / \mathrm{g}$ to $800 \mathrm{~mA} / \mathrm{g}$. The charge rate is fixed to $50 \mathrm{~mA} / \mathrm{g}$. (e) Capacity as a function of the discharge rate. 


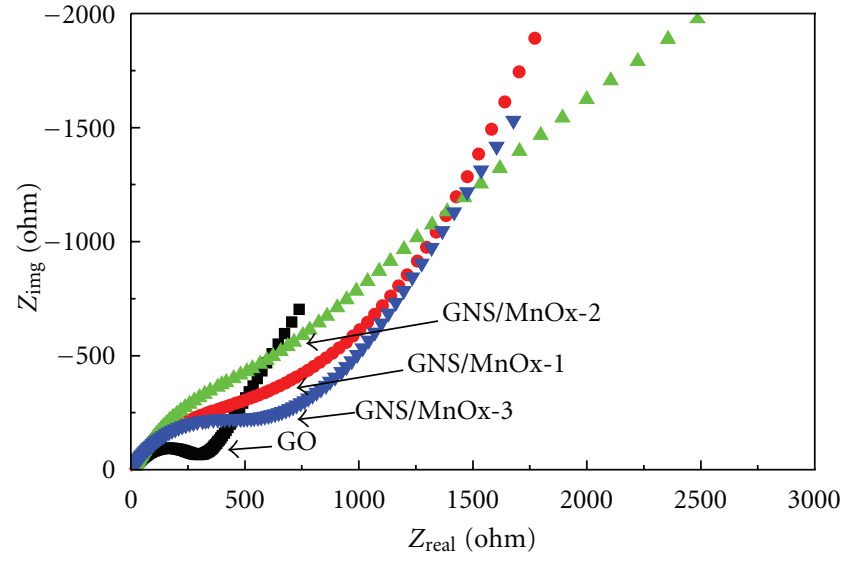

(a)

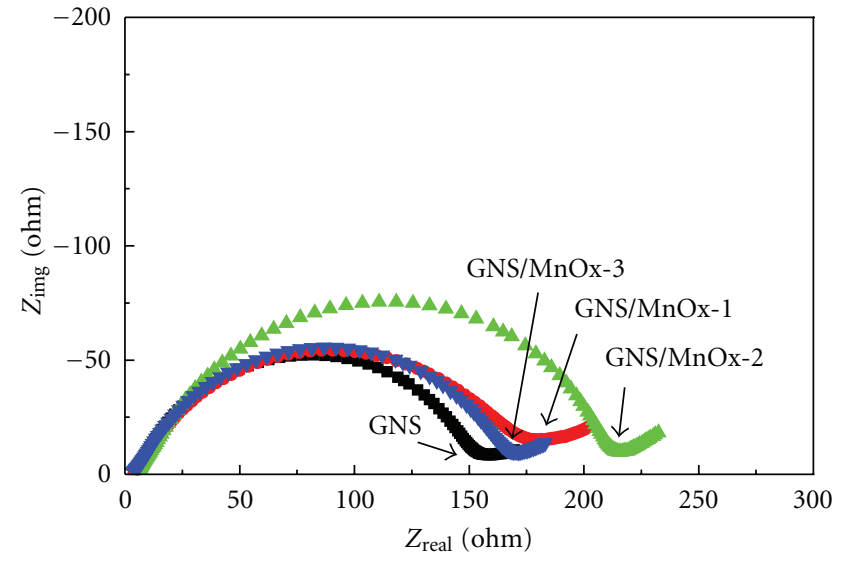

(b)

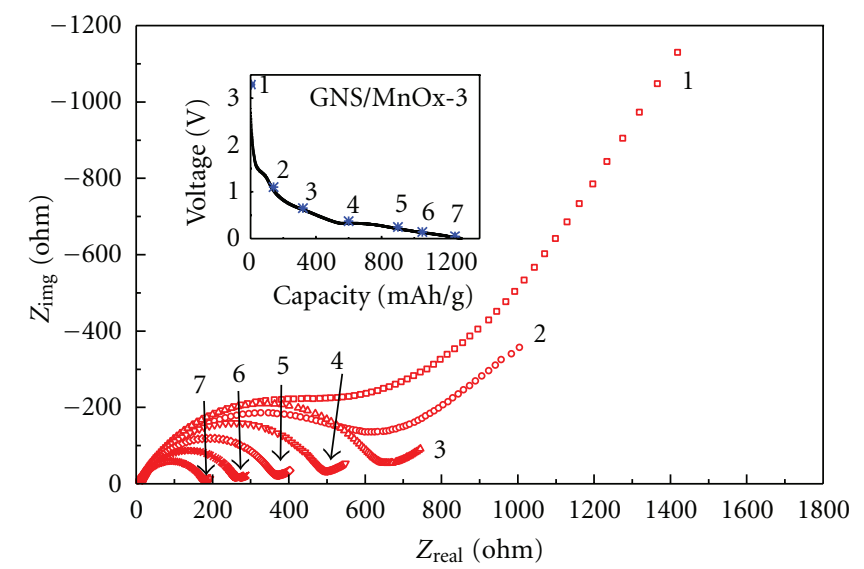

(c)

FIGURE 5: EIS Nyquist plots of (a) the cells consisting of different working electrode material at the open circuit voltage; (b) the cells consisting of different working electrode material at the fully discharge condition.

hybrids with different GNS contents and manganese valency. It is experimentally verified that $\mathrm{GNS} / \mathrm{MnO}_{x}$ with high content of GNS and $\mathrm{MnO}$ delivered the better performances. Nanoparticle MnOx anchored on the surface of GNS layers can be provided with continuous electrical paths from GNS to ensure fast electronic conduction. Further, GNS' mechanical flexibility is capable of mitigating the large volume change caused by the manganese oxide displacement reaction. GNS/MnO$x$ hybrids consisting of GNS $42 \mathrm{wt} \%$, $\mathrm{Mn}_{3} \mathrm{O}_{4} 23 \mathrm{wt} \%$, and $\mathrm{MnO} 35 \mathrm{wt} \%$ have a high reversibility capacity (up to $838 \mathrm{mAh} / \mathrm{g}$ ) with a high Coulombic efficiency $(65 \%)$, good cycling stability ( $0.8 \%$ fading per cycle), and high rate capability $(67 \%$ at the $800 \mathrm{~mA} / \mathrm{g})$. Its lithium storage potential centered around $0.5 \mathrm{~V}$ versus $\mathrm{Li}$ which is beneficial for the high rate capability and can also reduce the risk of metallic lithium formation and safety hazard.

\section{References}

[1] P. Poizot, S. Laruelle, S. Grugeon, L. Dupont, and J. M. Tarascon, "Nano-sized transition-metal oxides as negativeelectrode materials for lithium-ion batteries," Nature, vol. 407, no. 6803 , pp. 496-499, 2000.
[2] P. L. Taberna, S. Mitra, P. Poizot, P. Simon, and J. M. Tarascon, "High rate capabilities $\mathrm{Fe}_{3} \mathrm{O}_{4}$-based $\mathrm{Cu}$ nanoarchitectured electrodes for lithium-ion battery applications," Nature Materials, vol. 5, no. 7, pp. 567-573, 2006.

[3] G. A. Nazari and G. Pistoia, Lithium Batteries Science and Technology, Springer, 2009.

[4] M. M. Thackeray, W. I. F. David, and J. B. Goodenough, "Structural characterization of the lithiated iron oxides $\mathrm{LixFe}_{3} \mathrm{O}_{4}$ and $\mathrm{LixFe}_{2} \mathrm{O}_{3}(0<\mathrm{x}<2)$," Materials Research Bulletin, vol. 17, no. 6, pp. 785-793, 1982.

[5] M. M. Thackeray, W. I. F. David, P. G. Bruce, and J. B. Goodenough, "Lithium insertion into manganese spinels," Materials Research Bulletin, vol. 18, no. 4, pp. 461-472, 1983.

[6] T. Iijima, Y. Toyoguchi, J. Nishimura, and H. Ogawa, "Buttontype lithium battery using copper oxide as a cathode," Journal of Power Sources, vol. 5, no. 1, pp. 99-109, 1980.

[7] W. Yao, J. Yang, J. Wang, and L. Tao, "Synthesis and electrochemical performance of carbon nanofiber-cobalt oxide composites," Electrochimica Acta, vol. 53, no. 24, pp. 73267330, 2008.

[8] M. Y. Cheng and B. J. Hwang, "Mesoporous carbon-encapsulated $\mathrm{NiO}$ nanocomposite negative electrode materials for high-rate Li-ion battery," Journal of Power Sources, vol. 195, no. 15, pp. 4977-4983, 2010. 
[9] Y. L. Ding, C. Y. Wu, H. M. Yu et al., "Coaxial MnO/C nanotubes as anodes for lithium-ion batteries," Electrochimica Acta, vol. 56, no. 16, pp. 5844-5848, 2011.

[10] X. H. Huang, J. P. Tu, X. H. Xia, X. L. Wang, and J. Y. Xiang, "Nickel foam-supported porous NiO/polyaniline film as anode for lithium ion batteries," Electrochemistry Communications, vol. 10, no. 9, pp. 1288-1290, 2008.

[11] J. Guo, Q. Liu, C. Wang, and M. Zachariah, "Interdispersed amorphous $\mathrm{MnOx}$-carbon nanocompoites with superior electrochemical performance as lithium storage materials," Advanced Functional Materials, vol. 22, pp. 803-811, 2012.

[12] G. Zhou, D. W. Wang, F. Li et al., "Graphene-wrapped $\mathrm{Fe}_{3} \mathrm{O}_{4}$ anode material with improved reversible capacity and cyclic stability for lithium ion batteries," Chemistry of Materials, vol. 22, no. 18, pp. 5306-5313, 2010.

[13] P. Lian, X. Zhu, H. Xiang, Z. Li, W. Yang, and H. Wang, "Enhanced cycling performance of $\mathrm{Fe}_{3} \mathrm{O}_{4}$-graphene nanocomposite as an anode material for lithium-ion batteries," Electrochimica Acta, vol. 56, no. 2, pp. 834-840, 2010.

[14] Y. J. Mai, X. L. Wang, J. Y. Xiang et al., "CuO/graphene composite as anode materials for lithium-ion batteries," Electrochimica Acta, vol. 56, no. 5, pp. 2306-2311, 2011.

[15] H. Kim, D. H. Seo, S. W. Kim, J. Kim, and K. Kang, "Highly reversible $\mathrm{Co}_{3} \mathrm{O}_{4}$ /graphene hybrid anode for lithium rechargeable batteries," Carbon, vol. 49, no. 1, pp. 326-332, 2011.

[16] Y. J. Mai, S. J. Shi, D. Zhang, Y. Lu, C. D. Gu, and J. P. Tu, "NiO-graphene hybrid as an anode material for lithium ion batteries," Journal of Power Sources, vol. 204, pp. 155-161, 2012.

[17] Y. G. Zhu, G. S. Cao, J. Xie, T. J. Zhu, and X. B. Zhao, "NiO/graphene nanocomposite as anode material for lithiumion batteries," Nanoscience and Nanotechnology Letters, vol. 4, pp. 35-40, 2012.

[18] X. Xia, J. Tu, Y. Mai et al., "Graphene sheet/porous NiO hybrid film for supercapacitor applications," Chemistry - A European Journal, vol. 17, no. 39, pp. 10898-10905, 2011.

[19] H. Wang, L. F. Cui, Y. Yang et al., " $\mathrm{Mn}_{3} \mathrm{O}_{4}$-graphene hybrid as a high-capacity anode material for lithium ion batteries," Journal of the American Chemical Society, vol. 132, no. 40, pp. 13978-13980, 2010.

[20] S. L. Cheekati, Y. Xing, Y. Zhuang, and H. Huang, "Graphene platelets and their manganese composites for lithium ion batteries," ECS Transactions, vol. 33, no. 39, pp. 23-32, 2011.

[21] A. Yu, H. W. Park, A. Davies, D. C. Higgins, Z. Chen, and X. Xiao, "Free-standing layer-by-layer hybrid thin film of graphene- $\mathrm{MnO}_{2}$ nanotube as anode for lithium ion batteries," Journal of Physical Chemistry Letters, vol. 2, no. 15, pp. 18551860, 2011.

[22] H. Kim, S.-W. Kim, J. Hong, Y.-U. Park, and K. Kang, "Electrochemical and ex-situ analysis on manganese oxide/graphene hybrid anode for lithium rechargeable batteries," Journal of Materials Research, vol. 26, no. 20, pp. 2665-2671, 2011.

[23] S.-Y. Liu, J. Xie, Y.-X. Zheng, G.-S. Cao, T.-J. Zhu, and X.-B. Zhao, "Nanocrystal manganese oxide $\left(\mathrm{Mn}_{3} \mathrm{O}_{4}, \mathrm{MnO}\right)$ anchored on graphite nanosheet with improved electrochemical Li-storage properties," Electrochimica Acta, vol. 66, pp. 271-278, 2012.

[24] D. Pasero, N. Reeves, and A. R. West, "Co-doped $\mathrm{Mn}_{3} \mathrm{O}_{4}$ : a possible anode material for lithium batteries," Journal of Power Sources, vol. 141, no. 1, pp. 156-158, 2005.
[25] X. Fang, X. Lu, X. Guo et al., "Electrode reactions of manganese oxides for secondary lithium batteries," Electrochemistry Communications, vol. 12, no. 11, pp. 1520-1523, 2010.

[26] K. Zhong, X. Xia, B. Zhang, H. Li, Z. Wang, and L. Chen, "MnO powder as anode active materials for lithium ion batteries," Journal of Power Sources, vol. 195, no. 10, pp. 33003308, 2010.

[27] K. Zhong, B. Zhang, S. Luo et al., "Investigation on porous $\mathrm{MnO}$ microsphere anode for lithium ion batteries," Journal of Power Sources, vol. 196, no. 16, pp. 6802-6808, 2011.

[28] J. Gao, M. A. Lowe, and H. D. Abruña, "Spongelike nanosized $\mathrm{Mn}_{3} \mathrm{O}_{4}$ as a high-capacity anode material for rechargeable lithium batteries," Chemistry of Materials, vol. 23, no. 13, pp. 3223-3227, 2011. 

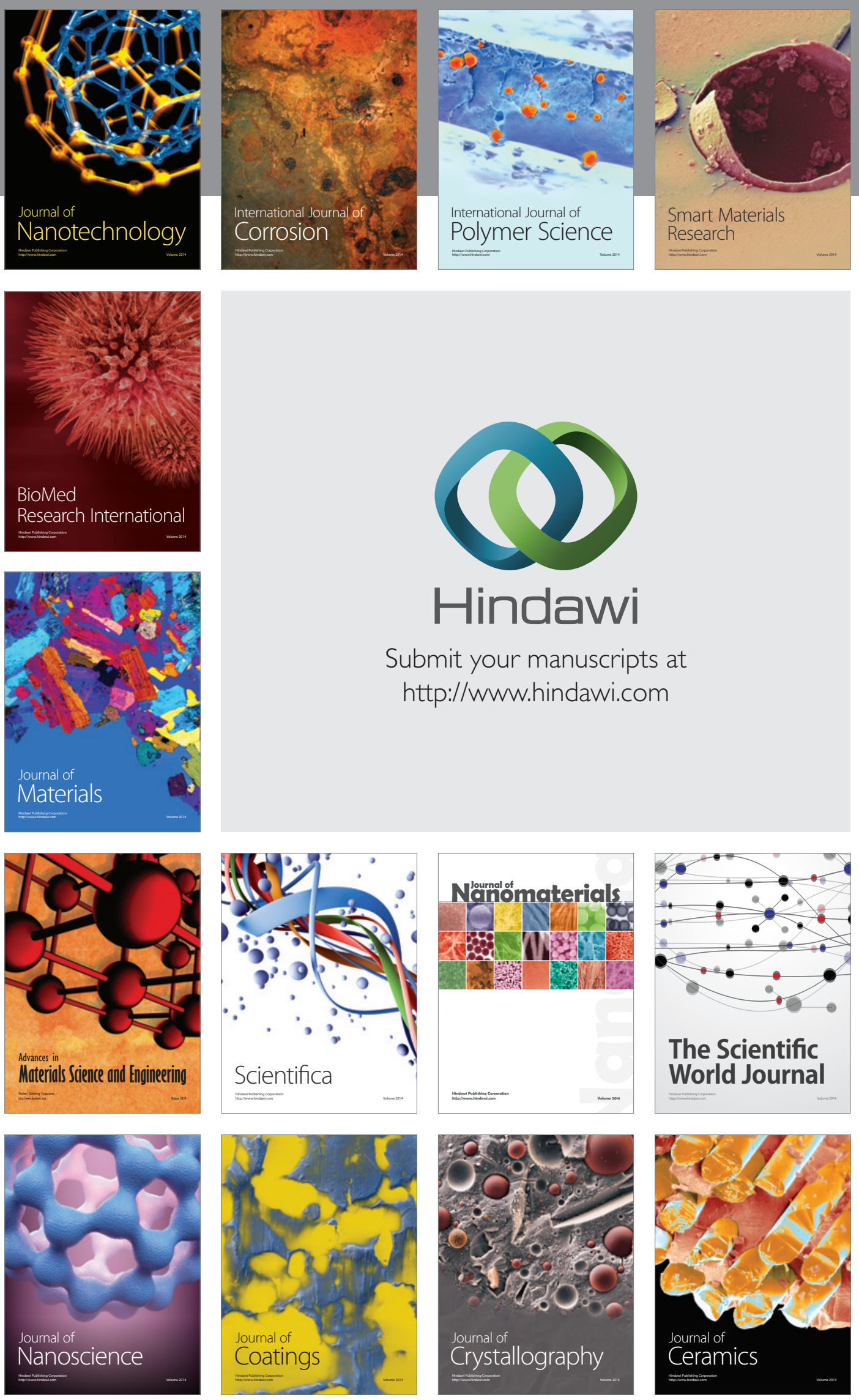

The Scientific World Journal

Submit your manuscripts at

http://www.hindawi.com

\section{World Journal}

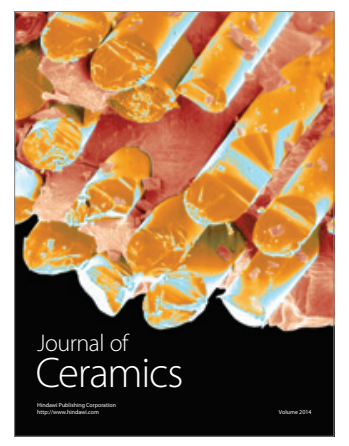

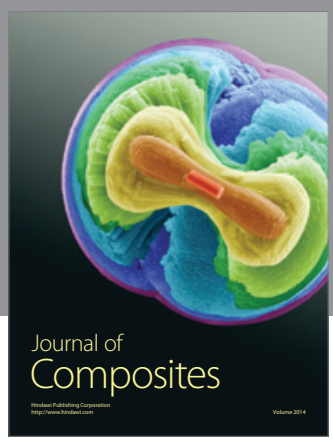
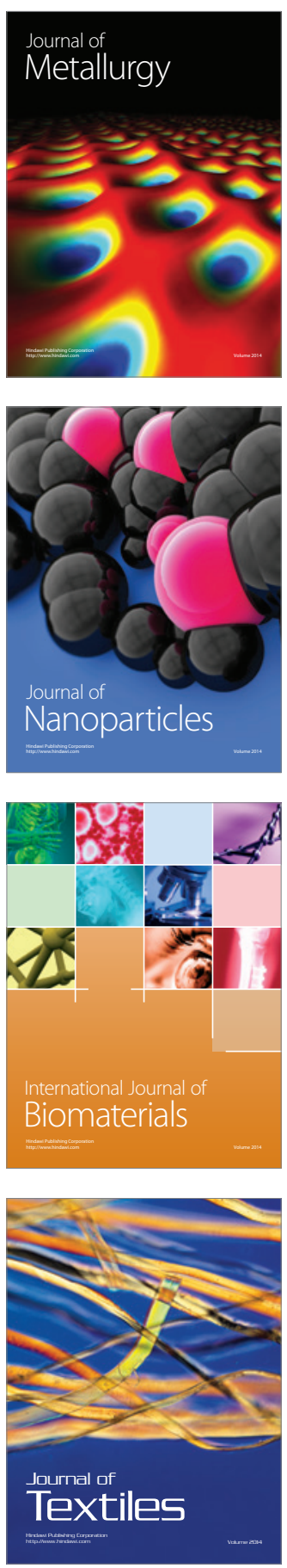